ARTYKUŁY

Studenckie Zeszyty Naukowe 2018, Vol. XXI, nr 38

DOI: 10.17951/szn.2018.21.38.71-86

\title{
Magdalena Sobas
}

Uniwersytet Śląski w Katowicach

magdalenasobas@interia.pl

\section{Orzeczenie Sądu Apelacyjnego w Białymstoku z dnia 24 kwietnia 2013 r. (I ACa 787/12). Rozważania dotyczące konsekwencji braku rzetelnej informacji o stanie pacjenta}

The Judgment of the Court of Appeals in Białystok of April 24, 2013 (I ACa 787/12). Considerations Regarding the Consequences of the Lack of Reliable Information about the Patient's Condition

\section{STRESZCZENIE}

W niniejszym artykule podjęto tematykę związaną z odpowiedzialnością za szkody prenatalne, a także z roszczeniami wrongful life oraz wrongful birth. Opracowanie jest próbą zdefiniowania pojęcia szkody w kontekście urodzenia się dziecka oraz ochrony dóbr osobistych rodziców w postaci prawa do planowania rodziny w przypadku przyjścia na świat dziecka z niepełnosprawnością. Tekst odnosi się również do obowiązku informacyjnego lekarza i personelu medycznego oraz jego zakresu i sposobu przekazywania pacjentowi informacji o jego stanie zdrowia.

Słowa kluczowe: obowiązek informacyjny; dobra osobiste; odpowiedzialność odszkodowawcza; badania prenatalne

\section{WSTĘP}

Człowiek, jako istota posiadająca cechy odróżniające od świata zwierząt, został wyposażony w katalog przysługujących mu praw, których fundamentem jest godność osoby ludzkiej, podkreślana w licznych opracowaniach zarówno prawnych, jak i moralnych, etycznych, socjologicznych czy teologicznych. W ostatnich latach można zaobserwować wzmożoną aktywność dyskursu społecznego dotyczącego początku życia ludzkiego, jego ochrony, a także praw kobiet, przyszłych matek oraz rodziców do podejmowania decyzji w zakresie tzw. wolności prokreacyjnej. 
Wolność ta jest ściśle związana z ochroną życia poczętego, a co za tym idzie również z doprecyzowaniem czy całkowitą zmianą w zakresie istniejących w polskiej kulturze prawnej przypadków, w których ustawodawca dopuszcza przerwanie ciąży ze względu na wady genetyczne dziecka czy dobro matki.

Z zagadnieniem początku ludzkiego życia, a także pierwszego jego etapu, jakim jest okres płodowy, wiążą się zagadnienia natury prawnej dotyczące odpowiedzialności za tzw. szkody prenatalne ${ }^{1}$ czy możliwość wystąpienia z roszczeniami $\mathrm{z}$ zakresu wrongful conception, wrongful birth czy wrongful life ${ }^{2}$. O ile w zakresie odpowiedzialności za szkody prenatalne istnieje bezsprzeczna podstawa prawna, na której można oprzeć żądanie naprawienia szkody, o tyle wrongful conception, wrongful birth i wrongful life stanowią swego rodzaju problem. Jego źródłem jest sposób rozumienia tych roszczeń (często związany ze sposobem pojmowania szkody), wdrożenie ich do polskiego systemu prawnego, a następnie oparcie na nich rozstrzygnięć sądów.

\section{OPIS STANU FAKTYCZNEGO}

Jednym z orzeczeń dotykających problematyki odszkodowawczej w zakresie urodzenia się dziecka z wadami wrodzonymi jest rozstrzygnięcie Sądu Apelacyjnego w Białymstoku z dnia 24 kwietnia 2013 r. ${ }^{3}$ Powód, małoletni D.R., reprezentowany przez przedstawicieli ustawowych D.R. i R.Z. (rodziców), wnosił o zasądzenie od pozwanego, Instytutu w W., zadośćuczynienia, a także zwrotu kosztów leczenia, dojazdów do placówek medycznych i kosztów żywienia dojelitowego.

1 W polskim prawie cywilnym podstawą dochodzenia roszczeń z tytułu szkód prenatalnych (tzw. prenatal injuries) jest przepis art. $446^{1}$ k.c. - ustawodawca przyznaje dziecku narodzonemu możliwość żądania naprawienia szkód doznanych jeszcze przed jego przyjściem na świat.

2 Wrongful life jest tłumaczone jako „,bezprawne spowodowanie życia”, „złe życie”, „nieszczęśliwe istnienie", ze względu na to, że obejmuje swym zakresem roszczenia odszkodowawcze dziecka, które przyszło na świat z wadami - psychicznymi bądź fizycznymi. Por. W. Sitek, Zadośćuczynienie w sprawach wrongful life w świetle prawa polskiego, „Państwo i Prawo” 2010, z. 8, s. 96; T. Justyński, Poczęcie i urodzenie się dziecka jako źródto odpowiedzialności cywilnej, Kraków 2003, s. 3; M. Bilecka, Proces o „złe urodzenie” (uwagi do wyroków Sądu Okręgowego w Łomży oraz Sądu Apelacyjnego w Białymstoku), „Prawo i Medycyna” 2005, nr 3; M. Nesterowicz, Glosa do wyroku Sądu Najwyższego z 13 października 2005 r., IV CK 161/05, „Orzecznictwo Sądów Polskich" 2006, nr 6, s. 71. Z kolei wrongful conception i wrongful birth swoim zakresem obejmują sytuacje, w których rodzice w ogóle nie chcieli, aby doszło do poczęcia dziecka, bądź nie chcieli, aby na świat przyszło dziecko upośledzone, co jednak nastąpiło w wyniku zawinionego działania lekarza. Por. T. Justyński, op. cit.

3 Wyrok SA w Białymstoku z dnia 24 kwietnia 2013 r., I ACa 787/12, http://orzeczenia.bialystok.sa.gov.pl [dostęp: 1.06.2018]. 
Powódka (matka dziecka) przebywała na oddziale psychiatrycznym jednego z pobliskich szpitali z rozpoznaniem nawracających zaburzeń depresyjnych. Poddała się badaniu ginekologicznemu, które potwierdziło jej podejrzenia co do ciąży (6. tydzień). Następnie zgłosiła się na badania prenatalne z racji tego, iż pierwsze dziecko przyszło na świat z chorobą K. Badanie płynu owodniowego pacjentki, co prawda, wykluczyło u płodu chorobę K., jednak wskazało na ewentualną możliwość nosicielstwa nieprawidłowej mutacji ${ }^{4}$. Na podstawie wyników przeprowadzonych badań prenatalnych powódka zdecydowała o urodzeniu dziecka. Po porodzie u małoletniego stwierdzono rozszczep wargi górnej, wyrostka zębodołowego szczęki oraz podniebienia twardego i miękkiego. Ponadto dziecko miało obustronny niedosłuch, a także problemy z układem pokarmowym i ze wzmożonym napięciem ciała. W konsekwencji u powoda zdiagnozowano chorobę K. ${ }^{5}$, która była powodem śmierci małoletniego w 15. miesiącu życia. Po śmierci dziecka jego matka przebywała w szpitalu z powodu złego stanu psychicznego objawiającego się myślami samobójczymi (podjęła nawet próbę samobójczą) i obniżonym nastrojem wywołanym chorobą syna.

Sąd Okręgowy w przedmiotowej sprawie uznał, iż doszło do naruszenia art. 24 kodeksu cywilnego ${ }^{6} \mathrm{w}$ zw. $\mathrm{z}$ art. 448 k.c., art. $4 \mathrm{a}$ ust. 1 ustawy z dnia 7 stycznia 1993 r. o planowaniu rodziny, ochronie płodu ludzkiego, warunkach dopuszczalności przerwania ciąży ${ }^{7}$, art. 444 k.c. w zw. z art. 361 § 1 i 2 k.c. przez Instytut w W., w którym powódka miała wykonywane badania prenatalne. W ocenie sądu działania

${ }^{4}$ „U płodu nie stwierdzono aberracji chromosomowych ani też wad otwartych cewy nerwowej, jednakże wykryto obniżony poziom enzymu galaktocerebrozydazy, który wedle wiedzy przeprowadzającego badanie przesądzał o heterozygotyczności, a nie patologii. W związku z powyższym uznano, iż płód nie jest dotknięty chorobą K. Płyn owodniowy pobierany do badań z amniopunkcji, z racji przerwania ciągłości tkanek kobiety w ciąży w pewnym stopniu jest zanieczyszczony komórkami i materiałem genetycznym matki, co wpływa na diagnostykę pobranego materiału pod względem genetycznym. Celem eliminacji zanieczyszczeń zakłada się tzw. hodowlę komórkową w warunkach faworyzujących wzrost komórek płodu - o fakcie tym powodowie nie zostali poinformowani przez lekarzy. W zakresie diagnostyki genetycznej w Polsce brak jest regulacji prawnych określających zasady, zakres i sposób przeprowadzania i dokumentowania badań diagnostycznych. Nie ma też wymogu akredytacji laboratorium diagnostycznego zgodnie z normą [...], która stanowi oprócz potwierdzenia kompetencji laboratorium w akredytowanej dziedzinie, opracowanie szczegółowej dokumentacji stosowanych procedur badawczych, ich walidacji, zasad interpretacji wyników, prowadzenia sprawdzeń kluczowej aparatury badawczej”.

5 Choroba K. jest chorobą genetyczną, niemożliwą do wyleczenia. Łączy się z dużym stopniem cierpienia i bólu, który łagodzony jest silnymi lekami. D.R. do śmierci wymagał karmienia sondą (6 butelek preparatu na dobę), został zakwalifikowany jako osoba z niepełnosprawnością, a powódce przyznano świadczenie pielęgnacyjne z tytułu rezygnacji z zatrudnienia lub innej pracy w związku z opieką nad dzieckiem.

6 Ustawa z dnia 24 kwietnia 1964 r. - Kodeks cywilny (Dz.U. z 2018 r., poz. 650), dalej jako: k.c.

7 Ustawa z dnia 7 stycznia 1993 r. o planowaniu rodziny, ochronie płodu ludzkiego, warunkach dopuszczalności przerwania ciąży (Dz.U. z 2001 r., nr 154, poz. 1792), dalej jako: u.p.r. 
pracowników miały charakter bezprawności naruszenia dóbr osobistych powodów. Bezprawność polegała na braku poinformowania powodów o niejednoznaczności i możliwości zafałszowania wyników wykonanych badań prenatalnych, a także na braku ich weryfikacji za pomocą badań genetycznych. Bezprawność stanowił też pisemny wniosek, iż wyniki badań wykluczają chorobę K. u płodu, w wyniku czego powódka podjęła decyzję o nieprzerwaniu ciąży. Brak profesjonalnej, rzetelnej informacji o stanie zdrowia uniemożliwił powodom skorzystanie z prawa do aborcji, a co za tym idzie godził $w$ ich prawo do planowania rodziny. W sprawie udowodniono, iż działanie Instytutu było również zawinione (wina nieumyślna w postaci niedbalstwa - wyciągnięcie kategorycznych wniosków wykluczających chorobę K. mimo świadomości ograniczeń badawczych występujących w kraju). Lekarze i personel medyczny mieli możliwość przewidzenia wystąpienia u D.R. choroby K. ze względu na to, że posiadają wiedzę co do niejednoznaczności badań prenatalnych i ich niedoskonałości.

Przeprowadzone przed Sądem Apelacyjnym dodatkowe dowody wskazały, iż badanie prenatalne, które zostało przeprowadzone u powódki przez pozwany Instytut, nie mogło być pod żadnym względem sklasyfikowane jako tzw. błąd w sztuce ${ }^{8}$.

Podsumowując, w opisanym stanie faktycznym Sąd Apelacyjny w Białymstoku stwierdził, że nie istnieją podstawy prawne do wystąpienia przez dziecko z roszczeniem, jakoby jego urodzenie się stanowiło szkodę w zakresie uniemożliwienia matce podjęcia decyzji co do przerwania ciąży. Sąd nie zgodził się też z tym, że małoletni miał prawo do nieurodzenia się w razie wystąpienia wad płodu, a także $\mathrm{z}$ istnieniem związku przyczynowego pomiędzy działaniem Instytutu a krzywdą i cierpieniem dziecka, zatem roszczenia $z$ tytułu wrongful birth i wrongful life nie były zasadne. Sąd nie zgodził się również z twierdzeniem, że doszło do naruszenia dóbr osobistych powodów, gdyż nie dopatrzył się bezprawności ani zawinienia w zakresie wykonanej diagnostyki prenatalnej. W związku z powyższym Sąd Apelacyjny oddalił powództwo w całości.

8 „Zabieg pobrania płynu owodniowego do badań dokonano w odpowiednim czasie. Zabieg amniopunkcji (amniopunkcja klasyczna w tym konkretnym przypadku) został przeprowadzony około 15. tygodnia ciąży powódki (uzasadniało to najniższe ryzyko powikłań w postaci poronienia lub uszkodzenia płodu, pozwalało również uzyskać odpowiednie ilości materiału do przeprowadzonych badań prenatalnych i zakończenia ich przed 24. tygodniem ciąży). Z kolei to biopsja trofoblastu (wykonywana między 9. a 12. tygodniem ciąży) wiąże się z relatywnie wysokim w stosunku do amniopunkcji ryzykiem uszkodzenia płodu, a także z ryzykiem zanieczyszczenia pobranego materiału - materiałem matczynym". 


\section{INFORMACJA O STANIE ZDROWIA W KONTEKŚCIE URODZENIA SIĘ DZIECKA}

Zagadnienia związane z ochroną zdrowia, podjęciem leczenia i jego dalszym procesem oraz z relacjami na linii pacjent - lekarz są jednymi z najistotniejszych i najbardziej aktualnych zarówno na gruncie nauk prawnych, jak i w sferze nauk medycznych. Od kilkunastu lat można obserwować z jednej strony stały wzrost poziomu świadomości w zakresie przysługujących człowiekowi praw (w tym praw pacjenta $)^{9}$, z drugiej zaś obowiązków, które personel medyczny zobowiązany jest spełniać $^{10}$. W odniesieniu do praw pacjenta istnieje możliwość wskazania dwóch kategorii praw ${ }^{11}$. Pierwszą stanowią administracyjno-socjalne obowiązki aparatu państwowego, których rolą jest zapewnienie jednostkom dostępu do adekwatnego i kompetentnego poziomu opieki zdrowotnej przy jednoczesnym wykluczeniu jakichkolwiek przejawów dyskryminacji w tym zakresie ${ }^{12}$. Drugą są uprawnienia ściśle związane z prawami człowieka ${ }^{13}$. Powiązanie to pozwala na odejście od twardego paternalizmu w stosunkach lekarz - pacjent na rzecz świadomości człowieka występującego w charakterze pacjenta i przysługujących mu praw podmiotowych ${ }^{14}$.

Na gruncie rozważanej tematyki powstają jednak pytania: Czy personel medyczny dopełnił spoczywającego na nim obowiązku informacyjnego? Czy w przypadku braku rzetelnej informacji, niejako uniemożliwiającej rodzicom podjęcie decyzji co do ewentualnej terminacji ciąży, przyjście na świat dziecka chorego stanowi szkodę?

\section{Prawo do informacji}

Niezwykle istotne w zakresie praw pacjenta jest prawo do uzyskania od personelu medycznego rzetelnej informacji na temat sytuacji zdrowotnej, w jakiej się znalazł. Informacja ta stanowi fundament podjęcia przez pacjenta dalszych decyzji co do zgody bądź odmowy w przedmiocie udzielenia świadczenia zdrowotnego ${ }^{15}$.

${ }^{9}$ A. Doroszewska, Socjologiczne aspekty praw pacjenta - analiza wybranych problemów, [w:] Uwarunkowania prawne, ekonomiczne i socjologiczne funkcjonowania wybranych systemów ochrony zdrowia, red. T. Mróz, Białystok 2011, s. 122.

${ }_{10}$ Aktami prawnymi dotyczącymi praw pacjenta są m.in.: ustawa $z$ dnia 6 listopada 2008 r. o prawach pacjenta i Rzeczniku Praw Pacjenta (Dz.U. z 2017 r., poz. 1524), dalej jako: u.p.p.; ustawa z dnia 5 grudnia 1996 r. o zawodach lekarza i lekarza dentysty (Dz.U. z 2018 r., poz. 697), dalej jako: u.z.l.

${ }_{11}$ D. Karkowska, Prawa pacjenta, Warszawa 2004, s. 35-36. Prawa człowieka, w tym również dziecka, w zakresie ochrony zdrowia oparte są na fundamencie, jakim jest konstytucyjne prawo do życia. Por. P. Winczorek, Komentarz do Konstytucji Rzeczypospolitej Polskiej, Warszawa 2000, s. 57.

${ }_{12}$ Ibidem. Por. P. Kuczma, Prawna ochrona życia, [w:] Realizacja i ochrona konstytucyjnych wolności i praw jednostki w polskim porządku prawnym, red. M. Jabłoński, Wrocław 2014, s. 34.

13 Ibidem.

${ }^{14}$ Ibidem.

15 Ż. Skrenty, Obowiazek informowania pacjenta wobec jego prawa do samostanowienia, „PWSZ IPiA Studia Lubelskie” 2015, t. 11, s. 104. 
Zgodnie z art. 31 ust. 1 u.z.l. na lekarzu spoczywa obowiązek udzielenia pacjentowi (jego przedstawicielowi ustawowemu lub innym osobom za zgodą pacjenta lub jego przedstawiciela ustawowego) przystępnej informacji o stanie zdrowia, rozpoznaniu, proponowanych oraz możliwych metodach diagnostycznych, leczniczych, dających się przewidzieć następstwach ich zastosowania albo zaniechania, wynikach leczenia oraz rokowaniu. Prawo pacjenta do informacji o stanie zdrowia zostało określone również w art. 9 u.p.p. Pacjent powinien uzyskać przystępną informację o stanie zdrowia, rozpoznaniu, proponowanych oraz możliwych metodach diagnostycznych i leczniczych, dających się przewidzieć następstwach ich zastosowania albo zaniechania, wynikach leczenia oraz rokowaniu.

Także na gruncie Kodeksu Etyki Lekarskiej ${ }^{16}$ na lekarza został nałożony obowiązek nie tylko respektowania prawa pacjenta do świadomego udziału w podejmowaniu decyzji dotyczących jego zdrowia, ale też udzielenia mu informacji. Informacja powinna być sformułowana w sposób zrozumiały dla pacjenta, a lekarz powinien poinformować o stopniu ewentualnego ryzyka zabiegów diagnostycznych i leczniczych oraz spodziewanych korzyściach związanych z wykonaniem tych zabiegów, a także o możliwościach zastosowania innego postępowania medycznego.

Sposób przekazania informacji jest niezwykle istotny. Jak zauważa M. Filar, powinna ona posiadać kilka $\operatorname{cech}^{17}$. Przede wszystkim informacja musi być przystępna, a zatem dopasowana do możliwości percepcyjnych i intelektualnych pacjenta ${ }^{18}$. Powinna być wszechstronna, czyli ma eksponować wszystkie możliwości, alternatywne metody badania, leczenia i możliwe rokowania ${ }^{19}$. Informacja przekazywana pacjentowi musi posiadać cechę rzetelności, czyli powinna być zobiektywizowana, nie może ograniczać danych dotyczących określonych skutków, aby w żaden sposób nie wpływać na dalsze decyzje pacjenta w przedmiocie leczenia ${ }^{20}$. Obowiązek informacyjny powinien być dokonywany w sposób adekwatnie szczegółowy, tzn. lekarz powinien opisać istotę problemu, konsekwencje, rokowania i alternatywy nie tylko te uznawane za standardowe, ale również niestandardowe, nawet w wypadku, gdy nie są one zakwalifikowane do kategorii świadczeń zdrowotnych finansowanych ze środków publicznych ${ }^{21}$. Pacjent powinien zostać poinformowany zarówno o powodach, dla których należy zastosować względem niego określoną czynność medyczną, jak i jej możliwych skutkach ${ }^{22}$. Zatem o granicach informa-

${ }^{16}$ Kodeks Etyki Lekarskiej - Przyrzeczenie Lekarskie, www.nil.org.pl/_data/assets/pdf_ file/0003/4764/Kodeks-Etyki-Lekarskiej.pdf [dostęp: 5.06.2018].

${ }_{17}$ M. Filar, Lekarskie prawo karne, Kraków 2000, s. 262-263.

18 Ibidem.

19 Ibidem.

${ }^{20}$ Ibidem.

${ }^{21}$ Ibidem.

${ }_{22}$ D. Karkowska, Komentarz do art. 9 ustawy o prawach pacjenta i Rzeczniku Praw Pacjenta, [w:] Ustawa o prawach pacjenta i Rzeczniku Praw Pacjenta, Warszawa 2012. 
cji przekazywanej pacjentowi w żadnym wypadku nie może decydować lekarz ${ }^{23}$. Nieprzekazanie informacji i jej ograniczenie nie może być wynikiem przekonań czy światopoglądu lekarza ${ }^{24}$.

Jak wynika z orzecznictwa, zakres obowiązku informacyjnego lekarza względem pacjenta nie może zależeć od osobistych przekonań lekarza co do tego, jaką ilość informacji należy przekazać pacjentowi, lecz zależy przede wszystkim od tego, jakie informacje osoba rozsądna znajdująca się w sytuacji pacjenta w sposób obiektywny życzy sobie poznać czy o jakich potrzebuje wiedzieć, aby podjąć świadomą decyzję co do dalszego postępowania medycznego ${ }^{25}$.

Jedyną możliwością, kiedy lekarz może ograniczyć zakres obowiązku informacyjnego, są sytuacje wyjątkowe, gdy rokowanie jest niepomyślne dla pacjenta (art. 31 ust. 4 u.z.1.), ale pod warunkiem, że w ocenie lekarza przemawia za tym dobro pacjenta. Co istotne, $w$ takich przypadkach lekarz ma obowiązek poinformowania przedstawiciela ustawowego pacjenta lub osobę przez niego upoważnioną. Zgodnie $\mathrm{z}$ art. 9 ust. 6 u.p.p. na żądanie pacjenta lekarz ma obowiązek udzielenia mu pełnej informacji $\mathrm{i}^{26}$.

W przedmiotowej sprawie personel medyczny miał niewątpliwie do czynienia z pacjentką w pełni kompetentną i świadomą ${ }^{27}$. Nie sposób zgodzić się z ograniczeniem przekazanej powodom informacji dotyczącej diagnostycznych badań prenatalnych, szczególnie w sytuacji, gdy pacjentka urodziła już wcześniej dziecko z chorobą K. Obowiązek informacyjny powinien obejmować nie tylko wiadomości dotyczące obecnej sytuacji pacjentki, ale również możliwych dalszych działań. Informacja ta powinna zawierać wszelkie możliwe nieścisłości w zakresie przeprowadzonego badania, a w szczególności lekarz powinien powodom wyjaśnić, w jaki sposób badanie jest przeprowadzane oraz że istnieje możliwość zafałszowania wyników, które następnie można zweryfikować za pomocą przeprowadzenia badań genetycznych, co względem powodów nie zostało uczynione.

Nie sposób nie zgodzić się z S. Poździochem, iż upowszechnienie dostępu do wiedzy medycznej i wzrost poziomu wiedzy społeczeństwa skutkują tym, że pacjent dąży do współodpowiedzialności za własny los, w tym za proces leczenia i jego konsekwencje czy efekty ${ }^{28}$.

${ }^{23}$ J. Ciechorski, Glosa do wyroku Sadu Apelacyjnego z dnia 28.11.2012 r., VACa 826/12, LEX nr 191600/2.

${ }^{24}$ M. Malczewska, Prawo do informacji, [w:] Ustawa o zawodach lekarza i lekarza dentysty. Komentarz, red. E. Zielińska, Warszawa 2014, s. 589.

${ }^{25}$ Wyrok SA w Poznaniu z dnia 29 września 2005 r., I ACa 236/05, LEX nr 175206; wyrok SN z dnia 8 lipca 2010 r., II CSK 117/10, LEX nr 602677.

26 Por. art. 17 Kodeksu Etyki Lekarskiej.

27 Por. M. Boratyńska, P. Konieczniak, Prawa pacjenta, Warszawa 2001, s. 230.

28 S. Poździoch, Prawa lekarza w systemie prawnym, [w:] Prawa lekarza. Zarys problematyki, red. S. Poździoch, M. Giński, Warszawa 2012, s. 50. 


\section{Urodzenie się dziecka jako rodzaj szkody}

W rozważanym stanie faktycznym kwestię fundamentalną stanowi pojęcie szkody. W polskim systemie prawnym nie funkcjonuje definicja legalna szkody, co sprawia, że zarówno w doktrynie, jak i judykaturze pojawiają się różne koncepcje na temat jej pojmowania ${ }^{29}$.

Sąd Okręgowy, rozpoznając niniejszą sprawę, wskazał, że naruszenie praw podmiotowych uzasadniało roszczenie odszkodowawcze obejmujące szkodę wynikającą z konieczności ponoszenia przez powodów zwiększonych kosztów utrzymania niepełnosprawnego dziecka, pozostających w związku przyczynowym z zaniedbaniami lekarzy Instytutu, którzy pozbawili rodziców możliwości zdecydowania o przerwaniu ciąży.

Szkoda jest często definiowana jako ,uszczerbek w dobrach poszkodowanego, polegający na różnicy między stanem tych dóbr powstałym wskutek zdarzenia szkodzącego a stanem, jaki by istniał, gdyby nie zaszło zdarzenie sprawcze"30, ewentualnie również jako „każdy uszczerbek w prawnie chronionych dobrach, który wyraża się w różnicy pomiędzy stanem dóbr, jaki już istniał i jaki mógłby następnie w normalnej kolei rzeczy wytworzyć się, a stanem, jaki powstał wskutek zdarzenia wywołującego zmianę w dotychczasowym stanie rzeczy, z którym to ustawodawca wiąże powstanie odpowiedzialności odszkodowawczej”31 lub „każdy uszczerbek w dobrach chronionych przez prawo"32 czy w końcu „wszelki uszczerbek majątkowy lub niemajątkowy" ${ }^{33}$.

Przedstawiciele nauki podkreślają, że szkoda może wystąpić nie tylko w formie szkody majątkowej, ponieważ nic nie stoi na przeszkodzie, aby przybrała postać szkody w dobrach niemajątkowych czy nawet krzywdy ${ }^{34}$. Pogląd ten nie spotkał się z ogólną aprobatą - część doktryny zauważa jednak, że w zakresie rozumienia pojęcia szkody należy raczej przyjąć wykładnię zawężającą, a tym samym ograniczyć szkodę tylko do uszczerbku w majątku poszkodowanego ${ }^{35}$. Należy podkreślić,

29 T. Justyński, op. cit., s. 10; A. Malinowski, Redagowanie tekstu prawnego. Wybrane wskazania logiczno-językowe, Warszawa 2008, s. 21-26, 44-48.

${ }^{30}$ M. Kaliński, Odpowiedzialność odszkodowawcza, [w:] System Prawa Prywatnego, t. 6: Prawo zobowiazań, red. A. Olejniczak, Warszawa 2009, s. 77.

31 T. Dybowski, [w:] System Prawa Cywilnego, t. 3, cz. 1: Prawo zobowiazań-część ogólna, red. Z. Radwański, Wrocław 1981, s. 214.

32 A. Ohanowicz, [w:] Zarys prawa zobowiazań, red. J. Górski, A. Ohanowicz, Warszawa 1970, s. 46.

33 A. Szpunar, Odszkodowanie za szkodę majątkową. Szkoda na mieniu i na osobie, Bydgoszcz 1998, s. 27.

34 J. Rezler, Naprawienie szkody wynikłej ze spowodowania uszczerbku na ciele lub zdrowiu (wedlug prawa cywilnego), Warszawa 1968, s. 19; W. Czachórski, A. Brzozowski, M. Safjan, S. Skowrońska-Bocian, Zobowiazania. Zarys wykładu, Warszawa 1999, s. 98.

${ }_{35}$ W. Warkałło, Odpowiedzialność odszkodowawcza - funkcje, rodzaje, granice, Warszawa 1972, s. 125 i n.; J. Winiarz, Ustalenie wysokości odszkodowania, Warszawa 1962, s. 16. 
iż osoba ponosząca odpowiedzialność za powstanie szkody zobowiązana jest także do jej naprawienia, $\mathrm{i}$ to w pełnym zakresie ${ }^{36}$.

Ze szkodą związane jest też pojęcie winy, stanowiące najstarszą fundamentalną zasadę odpowiedzialności cywilnej ${ }^{37}$. Wina, podobnie jak szkoda, nie została zdefiniowana prawnie ${ }^{38}$. Przyjmuje się, że wina ma miejsce w sytuacji, gdy podmiot wyrządzający szkodę zachowuje się obiektywnie lub subiektywnie w sposób niewłaściwy, nieodpowiedni ${ }^{39}$. Elementem obiektywnym jest bezprawność zachowania, rozumiana jako rozbieżność działania lub zaniechanie sprawcy z przepisem prawa czy zasadami współżycia społecznego ${ }^{40}$. Z kolei subiektywny charakter winy wyraża się w poczytalności, świadomości podmiotu dokonującego czynu, a co za tym idzie w negatywnej ocenie zachowania sprawcy ${ }^{41}$.

Wina podmiotu dokonującego szkody może wyrażać się również poprzez zaniechanie. Sytuacja taka ma miejsce, gdy określony podmiot był zobowiązany do działania, czego jednak nie uczynił, a wynikiem zaniechania jest wystąpienie szkody ${ }^{42}$.

Brak działania lekarza, polegającego na podjęciu dodatkowych czynności (np. w zakresie diagnostyki), w pewnych wypadkach może zostać uznany za niezachowanie należytej staranności w zakresie ustalenia przesłanek stanowiących podstawę prawidłowej diagnozy ${ }^{43}$. Na kanwie przytoczonego orzeczenia należy wskazać, że zarzutem powodów było niedochowanie należytej staranności przez lekarza wykonującego badanie w zakresie tego, iż nie potwierdził otrzymanych wyników mimo ich niejednoznaczności. Sąd Apelacyjny, rozpoznając sprawę, stwierdził jednak, że nie zauważa zawinienia po stronie pozwanego, a także jakiegokolwiek związku przyczynowo-skutkowego pomiędzy niewykryciem w badaniach choroby K. a krzywdą rodziców małoletniego.

Jako szkodę majątkową w omawianym stanie faktycznym można uznać jedynie skutki nieprzeprowadzenia zabiegu aborcji, i to tylko w odniesieniu do kobiety (której ustawodawca w wyjątkowych przypadkach na przeprowadzenie zabiegu przerwania ciąży zezwala), w rozumieniu wydatków związanych z ciążą i porodem oraz ewentualnymi utraconymi zarobkami w następstwie tych zdarzeń ${ }^{44}$.

${ }^{36}$ L. Stecki, Zasada petnej kompensacji szkody. Zagadnienia wybrane, [w:] Rozprawy z prawa cywilnego. Księga pamiątkowa ku czci Witolda Czachórskiego, red. J. Błeszyński, J. Rajski, Warszawa 1985, s. 229.

${ }_{37}$ M. Serwach, Wina jako zasada odpowiedzialności cywilnej oraz okoliczność zwalniająca z obowiązku naprawienia szkody, „Wiadomości Ubezpieczeniowe. Rozprawy Naukowe” 2009, nr 1, s. 84.

${ }^{38}$ Ibidem, s. 86.

${ }^{39}$ Ibidem.

40 Ibidem.

${ }^{41}$ Wyrok SN z dnia 26 września 2003 r., IV CK 32/02.

${ }_{42}$ M. Serwach, op. cit., s. 88.

${ }^{43}$ Wyrok SN z dnia 20 maja 2005 r., III CK 595/04.

44 A. Rogowska, Szkoda w polskim orzecznictwie dotyczacym ,złego urodzenia”, www.bibliotekacyfrowa.pl/Content/42769/34_Aleksandra_Rogowska.pdf [dostęp: 5.06.2018]. 
W kulturze europejskiej nie do zaakceptowania jest teoria, zgodnie z którą przyjście na świat dziecka byłoby rozumiane w kategorii szkody. Koncepcja ta jest niemożliwa do zaaprobowania m.in. ze względu na to, że w prawie cywilnym, jak już zostało wspomniane, szkodę pojmuje się jako zaistnienie uszczerbku w dobrach prawnych poprzez ich pomniejszenie lub zniszczenie ${ }^{45}$. W przypadku przyjścia na świat dziecka zazwyczaj doszukuje się wzrostu wartości ${ }^{46}$. Urodzenie się dziecka w aspekcie społecznym jest pojmowane jako jedno z najwyższych dóbr bez względu na sytuację ekonomiczną, społeczną czy nawet osobistą rodziców, a także rodziny jako całości ${ }^{47}$. Pogląd ten wydaje się być słuszny chociażby ze względu na to, iż przyjście na świat dziecka to powołanie do życia nowego człowieka, a zatem życie staje się wartością nadrzędną, które w żadnym wypadku nie powinno być rozumiane jako uszczerbek. Gdyby przyjąć, iż przyjście na świat dziecka z chorobą czy niepełnosprawnością stanowiło szkodę, wówczas mogłoby to doprowadzić do swego rodzaju „wartościowania życia” czy kategoryzacji na życie „lepsze” i „gorsze” albo życie „łatwiejsze” i „trudniejsze”. Dopuszcza się jednak twierdzenie odnoszące się do kosztów utrzymania dziecka. Wówczas koszty, jakie ponoszą rodzice, dotyczą nie tylko zapewnienia bytu dzieciom zdrowym, ale także takim, które przyszły na świat z niepełnosprawnością zarówno fizyczną, jak i umysłową czy chorobą ${ }^{48}$. Tezę tę aprobuje również W. Borysiak, który stwierdził, iż:

[...] urodzenie się dziecka, nawet jeśli jest upośledzone, nie może być w żadnym wypadku uznane za szkodę. Natomiast uznanie wystąpienia i wyliczenie szkody - wydatków, które muszą ponosić rodzice upośledzonego dziecka - oraz stwierdzenie adekwatnego związku przyczynowego może być często kwestią sporną. Wydaje się, że w takich sytuacjach, ze względów słusznościowych, konieczne jest zapewnienie rodzinie godziwych warunków utrzymania ${ }^{49}$.

Sąd Apelacyjny, rozpatrując niniejszą sprawę, także stwierdził, że urodzenie się małoletniego $\mathrm{z}$ wadą genetyczną w żadnym wypadku nie może zostać potraktowane jako szkoda. Nie do zaakceptowania stało się więc rozstrzygnięcie sądu I instancji w przedmiotowej sprawie, który stwierdził, że małoletni mógł się nie narodzić, w efekcie czego nie doznałby cierpień związanych z chorobą, z kolei rodzicom należy się zadośćuczynienie wskutek pozbawienia ich możliwości decyzyjności w przedmiocie aborcji.

45 T. Justyński, op. cit., s. 54.

46 Ibidem.

47 Ibidem.

48 Ibidem.

49 W. Borysiak, Glosa do wyroku SN z dnia 13 października 2005 roku, IV CK 161/05, LEX nr 53382 (glosa krytyczna). 


\section{NARUSZENIE DÓBR OSOBISTYCH}

Katalog dóbr osobistych przysługujących każdemu podmiotowi prawa został określony w art. 23 k.c. Ma on charakter zbioru otwartego, co jednocześnie pozwala na pewien zakres swobody określenia innych desygnatów.

W odniesieniu do dóbr osobistych, podobnie jak w przypadku szkody i winy, nie istnieje definicja legalna ${ }^{50}$. Wskazuje się jednakże, iż dobra osobiste należy rozumieć jako wartości o charakterze niemajątkowym, powszechnie uznane w społeczeństwie, które są ściśle związane z osobowością człowieka ${ }^{51}$. Dla istnienia danego dobra osobistego, a co za tym idzie objęcia go w następnej kolejności ochroną w przypadku naruszenia, wymaga się, aby reprezentowało ono zasadnicze wartości społeczne $^{52}$. S. Grzybowski, podejmując rozważania na temat dóbr osobistych, wskazał, iż „ich wspólną charakterystyczną cechą są niemajątkowe, indywidualne wartości świata uczuć, stanu życia psychicznego człowieka"53.

Jednocześnie nie jest możliwe spojrzenie na człowieka, z punktu widzenia ochrony dóbr osobistych, jako tylko na organizm biologiczny ${ }^{54}$. Jak podkreśla Z. Radwański, nic nie stoi na przeszkodzie, aby wartości zdobyły obiektywną (intersubiektywną) rangę na skutek ich społecznej i prawnej aprobaty, a także powiązania z osobą ludzką ${ }^{55}$.

Należy zauważyć, iż dobra osobiste nie są kategorią zamykającą się czy funkcjonującą jedynie w sferze cywilnoprawnej. Biorąc pod uwagę ich niezwykle szeroki zakres, wskazuje się, że wiele z nich (jak chociażby prawna ochrona życia czy

${ }^{50}$ M. Borkowski, Zdrowie jako dobro osobiste, „Periodyk Naukowy Akademii Polonijnej” 2010, nr 1(4), http://docplayer.pl/1007252-Zdrowie-jako-dobro-osobiste.html [dostęp: 6.06.2018].

51 A. Szpunar, Ochrona dóbr osobistych, Warszawa 1979, s. 106. Por. wyrok SN z dnia 10 czerwca 1977 r., II CR187/77; wyrok SN z dnia 16 stycznia 1976 r., II CR 692/75, OSNCP 1976, nr 11, poz. 251; wyrok SN z dnia 23 maja 2002 r., IV CKN 1076/00; wyrok SN z dnia 28 lutego 2003 r., V CK 308/02; wyrok SA w Łodzi z dnia 10 lutego 2016 r., I ACr 341/96.

52 P. Księżak, Komentarz do art. 23 Kodeksu cywilnego, [w:] Kodeks cywilny. Komentarz. Część ogólna, red. P. Księżak, M. Pyziak-Szafnicka, Warszawa 2014.

53 S. Grzybowski, Ochrona dóbr osobistych według przepisów ogólnych prawa cywilnego, Warszawa 1957, s. 78. Por. B. Gawlik, Ochrona dóbr osobistych. Sens i nonsens tzw. praw podmiotowych osobistych, „Zeszyty Naukowe Uniwersytetu Jagiellońskiego. Prace z Wynalazczości i Ochrony Własności Intelektualnej” 1985, nr 4, s. 124. Koncepcja ta została skrytykowana m.in. przez: A. Kopffa (Koncepcja praw do intymności i do prywatności życia osobistego (zagadnienia konstrukcyjne), „Studia Cywilistyczne” 1972, t. 20) i A. Cisek (Dobra osobiste i ich niemajątkowa ochrona w kodeksie cywilnym, „Acta Universitatis Wratislaviensis. Prawo” 1989, t. 167).

54 Z. Radwański, Koncepcja praw podmiotowych osobistych, „Ruch Prawniczy, Ekonomiczny i Społeczny" 1988, nr 2, s. 6.

${ }_{55}$ Ibidem. Por. A. Szpunar, Ochrona dóbr ..., s. 106; Z. Radwański, Zarys części ogólnej prawa cywilnego, Warszawa 1979, s. 132; J. Panowicz-Lipska, Majątkowa ochrona dóbr osobistych, Warszawa 1975, s. 40-49; J.S. Piątowski, Ewolucja ochrony dóbr osobistych, [w:] Tendencje rozwoju prawa cywilnego, red. E. Łętowska, Wrocław 1983, s. 21 i n.; B. Gawlik, op. cit., s. 126. 
zasada równego dostępu do świadczeń zdrowotnych) zostało zawartych w ustawie zasadniczej ${ }^{56}$. Ponadto T. Sokołowski w kategorii dóbr osobistych wyróżnia dobra przyrodzone, których istnienie nie jest zależne od woli ustawodawcy (życie, zdrowie, godność), a ich zakres wyznacza tylko prawo pozytywne, którego stosunek do dóbr jest określony wyłącznie deklaratywnie ${ }^{57}$.

Ochrona dóbr osobistych w postaci życia i zdrowia została zagwarantowana zarówno w Konstytucji i prawie cywilnym, jak i w prawie karnym czy aktach europejskich. A. Zoll wskazał, iż prawo do ochrony zdrowia nie jest jedynie prawem gwarantowanym i nadawanym przez aparat państwa, ponieważ wynika ono z godności człowieka, którą władza ma obowiązek chronićs ${ }^{58}$. Zarazem prawo do zachowania najwyższego poziomu zdrowia jest poczytywane jako jedno z praw człowieka ${ }^{59}$.

W omawianym orzeczeniu Sąd Apelacyjny stwierdził, iż nie doszło do naruszenia dóbr osobistych powodów w oparciu o art. 24 i 448 k.c. oraz art. 4a u.p.r. i art. 4 u.z.l. Powodowie swe roszczenia opierali na zarzucie bezprawnego odebrania możliwości planowania rodziny, a także podjęcia ewentualnej decyzji o możliwości zakończenia ciąży. Sąd jednakże nie dopatrzył się cechy bezprawności w zachowaniu pozwanego ani winy w interpretacji wyników przeprowadzonego badania prenatalnego, gdyż - mimo niezgodności wyniku ze stanem rzeczywistym - jego wykonanie nie nosiło cech błędu w sztuce lekarskiej. Na tym tle należy wskazać, iż odwołanie do ochrony dóbr osobistych zawiera również art. $4 \S 1$ u.p.p., który stanowi, że w razie zawinionego naruszenia praw pacjenta sąd może przyznać poszkodowanemu odpowiednią sumę tytułem zadośćuczynienia pieniężnego za doznaną krzywdę na podstawie art. 448 k.c. Przepis ten nie znajduje jednak zastosowania m.in. w przypadku zawinionego naruszenia prawa pacjenta do informacji o rodzaju i zakresie świadczeń zdrowotnych udzielanych przez podmioty udzielające świadczeń zdrowotnych. Konstrukcja przepisu art. 4 § 1 u.p.p. wskazuje na rozszerzenie katalogu dóbr osobistych o takie prawa pacjenta, jak np. prawo do informacji czy prawo do świadczeń zdrowotnych ${ }^{60}$.

Wydaje się, że personel medyczny powinien poinformować rodziców dziecka o możliwej ewentualnej rozbieżności pomiędzy uzyskanym wynikiem badania a jego rzeczywistym rezultatem, mimo tego, iż działania w zakresie wykonania badania nie nosiły cech błędu w sztuce lekarskiej. W tym przypadku nawet zachowanie wyższej niż wymagana względem lekarzy staranności bezwzględnie

\footnotetext{
${ }^{56}$ T. Sokołowski, Komentarz do art. 23 Kodeksu cywilnego, [w:] Kodeks cywilny. Komentarz,
} t. 1: Część ogólna, red. A. Kidyba, Warszawa 2012.

57 Ibidem.

58 A. Zoll, Problemy stużby zdrowia w świetle doświadczeń RPO, „Prawo i Medycyna” 2000, nr 8, s. 16. Por. wyrok TK z dnia 7 stycznia 2004 r., K 14/2003, OTK ZU 2004, nr 1A, poz. 1.

${ }^{59}$ A. Łopatka, Jednostka. Jej prawa człowieka, Warszawa 2002, s. 229.

${ }^{60} \mathrm{M}$. Borkowski, op. cit. 
powinno mieć miejsce, chociażby $\mathrm{z}$ racji tego, iż parze wcześniej urodziło się dziecko z dokładnie taką samą chorobą, jak choroba małoletniego. Świadomość co do ewentualnych rozbieżności, nawet jeżeli byłyby one nieznaczne, pozwoliłaby powodom podjąć decyzję co do urodzenia się dziecka czy przygotować się na przyjście na świat dziecka z chorobą. W wyniku dalszej diagnostyki, już po narodzinach dziecka, nie przeżyliby oni szoku, dowiadując się o jego chorobie. Uniknęliby też poczucia bezradności i braku nadziei na poprawę stanu zdrowia małoletniego. Warto podkreślić, iż Sąd Najwyższy do kategorii dóbr osobistych zaklasyfikował nie tylko prawo do planowania rodziny, którego następstwem jest prawo do legalnego przerwania ciąży, ale też prawo do rzetelnej informacji o stanie nasciturusa ${ }^{61}$. Należałoby zatem zadać pytanie, czy w przedstawionym stanie faktycznym informacja ta nie powinna obejmować także możliwości przeprowadzenia dalszej diagnostyki, np. w zakresie badań genetycznych, które jednoznacznie przesądziłyby o występowaniu choroby u małoletniego.

\section{PODSUMOWANIE}

Przedstawione w niniejszym tekście rozważania stanowią tylko wycinek problemów wpisujących się w zagadnienia dotyczące ochrony zdrowia dziecka poczętego, prawa do badań prenatalnych, informowania pacjenta o jego stanie zdrowia i możliwych metodach diagnostyczno-leczniczych, roszczeń z zakresu wrongful birth i wrongful life oraz ich relacji do odpowiedzialności za szkody prenatalne.

We współczesnym świecie rozwój medycyny i nauk pokrewnych doprowadził do sytuacji, w której lekarze i personel medyczny dysponują nowoczesnymi metodami wykrywania, przeciwdziałania i ewentualnego leczenia pacjentów. Niejednokrotnie jednak innowacyjna technologia w zakresie medycyny i biotechnologii zderza się z licznymi zaniedbaniami ze strony człowieka, niedoinformowaniem pacjenta czy brakiem środków na sfinansowanie wykonania kolejnych, bardziej szczegółowych badań.

W omawianej sprawie Sąd Apelacyjny zmierzył się z problemem ochrony dóbr osobistych, w szczególności w postaci prawa do planowania rodziny, a co za tym idzie uniemożliwienia rodzicom podjęcia decyzji co do ewentualnej aborcji. Również rozumienie pojęcia szkody w przedmiotowej sprawie nie było oczywiste, co potwierdzają poglądy doktryny.

Jednym z zagadnień, jakie rozstrzygał Sąd Apelacyjny, jest też relacja dóbr osobistych dziecka w stosunku do dóbr osobistych jego rodziców. W doktrynie pojawiają się poglądy, zgodnie z którymi w sprawach z zakresu wrongful life nie można mówić o naruszeniu dóbr, gdyż przyjście na świat dziecka z niepełnospraw-

${ }^{61}$ Wyrok SN z dnia 12 czerwca 2008 r., II CSK 16/08. 
nością czy chorobą genetyczną nie jest konsekwencją działania jakiegokolwiek podmiotu, lecz jedynie skutkiem poczęcia i patologicznych zmian biologicznych czy genetycznych ${ }^{62}$. Oczywiście należy się zgodzić z tym poglądem, lecz w przypadku omawianej sprawy istniała możliwość wykonania dodatkowych badań genetycznych, o których rodzice nie wiedzieli.

$\mathrm{Na}$ gruncie rozważanej problematyki i wskazanego stanu faktycznego w odniesieniu do roszczeń wrongful life i wrongful birth pojawia się pytanie: Czy życie i funkcjonowanie osoby z niepełnosprawnością lub osoby, która przyszła na świat z wadą wrodzoną, jest mniej wartościowe od życia osoby, która urodziła się bez jakichkolwiek „defektów”?

\section{BIBLIOGRAFIA}

Bilecka M., Proces o ,złe urodzenie” (uwagi do wyroków Sądu Okręgowego w Lomży oraz Sądu Apelacyjnego w Białymstoku), „Prawo i Medycyna” 2005, nr 3.

Boratyńska M., Konieczniak P., Prawa pacjenta, Warszawa 2001.

Borkowski M., Zdrowie jako dobro osobiste, „Periodyk Naukowy Akademii Polonijnej” 2010, nr 1(4), http://docplayer.pl/1007252-Zdrowie-jako-dobro-osobiste.html [dostęp: 6.06.2018].

Borysiak W., Glosa do wyroku SN z dnia 13 października 2005 roku, IV CK 161/05, LEX nr 53382 (glosa krytyczna).

Ciechorski J., Glosa do wyroku Sadu Apelacyjnego z dnia 28.11.2012 r., V ACa 826/12, LEX nr 191600/2.

Cisek A., Dobra osobiste i ich niemajątkowa ochrona w kodeksie cywilnym, „Acta Universitatis Wratislaviensis. Prawo" 1989, t. 167.

Czachórski W., Brzozowski A., Safjan M., Skowrońska-Bocian S., Zobowiązania. Zarys wykładu, Warszawa 1999.

Doroszewska A., Socjologiczne aspekty praw pacjenta - analiza wybranych problemów, [w:] Uwarunkowania prawne, ekonomiczne i socjologiczne funkcjonowania wybranych systemów ochrony zdrowia, red. T. Mróz, Białystok 2011.

Dybowski T., [w:] System Prawa Cywilnego, t. 3, cz. 1: Prawo zobowiazań - część ogólna, red. Z. Radwański, Wrocław 1981.

Fila M., Lekarskie prawo karne, Kraków 2000.

Gawlik B., Ochrona dóbr osobistych. Sens i nonsens tzw. praw podmiotowych osobistych, „Zeszyty Naukowe Uniwersytetu Jagiellońskiego. Prace z Wynalazczości i Ochrony Własności Intelektualnej" 1985, $\mathrm{nr} 4$.

Grzybowski S., Ochrona dóbr osobistych wedlug przepisów ogólnych prawa cywilnego, Warszawa 1957.

Justyński T., Poczęcie i urodzenie się dziecka jako źródło odpowiedzialności cywilnej, Kraków 2003.

Kaliński M., Odpowiedzialność odszkodowawcza, [w:] System Prawa Prywatnego, t. 6: Prawo zobowiązań, red. A. Olejniczak, Warszawa 2009.

${ }^{62}$ M. Soniewiecka, Regulacje prawne wobec rozwoju nowoczesnych technik kontroli prokreacji: analiza roszczenia wrongful life, „Diametros” 2009, nr 19, s. 142. 
Karkowska D., Komentarz do art. 9 ustawy o prawach pacjenta i Rzeczniku Praw Pacjenta, [w:] Ustawa o prawach pacjenta i Rzeczniku Praw Pacjenta, Warszawa 2012.

Karkowska D., Prawa pacjenta, Warszawa 2004.

Kodeks Etyki Lekarskiej - Przyrzeczenie Lekarskie, www.nil.org.pl/_data/assets/pdf_file/0003/4764/ Kodeks-Etyki-Lekarskiej.pdf [dostęp: 5.06.2018].

Kopff A., Koncepcja praw do intymności i do prywatności życia osobistego (zagadnienia konstrukcyjne), „Studia Cywilistyczne” 1972, t. 20.

Księżak P., Komentarz do art. 23 Kodeksu cywilnego, [w:] Kodeks cywilny. Komentarz. Część ogólna, red. P. Księżak, M. Pyziak-Szafnicka, Warszawa 2014.

Kuczma P., Prawna ochrona życia, [w:] Realizacja i ochrona konstytucyjnych wolności i praw jednostki w polskim porzadku prawnym, red. M. Jabłoński, Wrocław 2014.

Łopatka A., Jednostka. Jej prawa człowieka, Warszawa 2002.

Malczewska M., Prawo do informacji, [w:] Ustawa o zawodach lekarza i lekarza dentysty. Komentarz, red. E. Zielińska, Warszawa 2014.

Malinowski A., Redagowanie tekstu prawnego. Wybrane wskazania logiczno-językowe, Warszawa 2008.

Nesterowicz M., Glosa do wyroku Sądu Najwyższego z 13 października 2005 r., IV CK 161/05, „Orzecznictwo Sąów Polskich” 2006, nr 6.

Ohanowicz A., [w:] Zarys prawa zobowiązań, red. J. Górski, A. Ohanowicz, Warszawa 1970.

Panowicz-Lipska J., Majątkowa ochrona dóbr osobistych, Warszawa 1975.

Piątowski J.S., Ewolucja ochrony dóbr osobistych, [w:] Tendencje rozwoju prawa cywilnego, red. E. Łętowska, Wrocław 1983.

Poździoch S., Prawa lekarza w systemie prawnym, [w:] Prawa lekarza. Zarys problematyki, red. S. Poździoch, M. Giński, Warszawa 2012.

Radwański Z., Koncepcja praw podmiotowych osobistych, „Ruch Prawniczy, Ekonomiczny i Społeczny" 1988, nr 2.

Radwański Z., Zarys części ogólnej prawa cywilnego, Warszawa 1979.

Rezler J., Naprawienie szkody wyniktej ze spowodowania uszczerbku na ciele lub zdrowiu (wedtug prawa cywilnego), Warszawa 1968.

Rogowska A., Szkoda w polskim orzecznictwie dotyczacym ,złego urodzenia”, www.bibliotekacyfrowa.pl/Content/42769/34_Aleksandra_Rogowska.pdf [dostęp: 5.06.2018].

Serwach M., Wina jako zasada odpowiedzialności cywilnej oraz okoliczność zwalniajaca z obowiązu naprawienia szkody, „Wiadomości Ubezpieczeniowe. Rozprawy Naukowe” 2009, nr 1.

Sitek W., Zadośćuczynienie w sprawach wrongful life w świetle prawa polskiego, „Państwo i Prawo” 2010, z. 8.

Skrenty Ż., Obowiazek informowania pacjenta wobec jego prawa do samostanowienia, „PWSZ IPiA Studia Lubelskie" 2015, t. 11.

Sokołowski T., Komentarz do art. 23 Kodeksu cywilnego, [w:] Kodeks cywilny. Komentarz, t. 1: Część ogólna, red. A. Kidyba, Warszawa 2012.

Soniewiecka M., Regulacje prawne wobec rozwoju nowoczesnych technik kontroli prokreacji: analiza roszczenia wrongful life, „Diametros” 2009, nr 19.

Stecki L., Zasada petnej kompensacji szkody. Zagadnienia wybrane, [w:] Rozprawy z prawa cywilnego. Księga pamiątkowa ku czci Witolda Czachórskiego, red. J. Błeszyński, J. Rajski, Warszawa 1985.

Szpunar A., Ochrona dóbr osobistych, Warszawa 1979.

Szpunar A., Odszkodowanie za szkodę majątkową. Szkoda na mieniu i na osobie, Bydgoszcz 1998.

Ustawa z dnia 24 kwietnia 1964 r. - Kodeks cywilny (Dz.U. z 2018 r., poz. 650).

Ustawa z dnia 7 stycznia 1993 r. o planowaniu rodziny, ochronie płodu ludzkiego, warunkach dopuszczalności przerwania ciąży (Dz.U. z 2001 r., nr 154, poz. 1792).

Ustawa z dnia 5 grudnia 1996 r. o zawodach lekarza i lekarza dentysty (Dz.U. z 2018 r., poz. 697). 
Ustawa z dnia 6 listopada 2008 r. o prawach pacjenta i Rzeczniku Praw Pacjenta (Dz.U. z 2017 r., poz. 1524).

Warkałło W., Odpowiedzialność odszkodowawcza - funkcje, rodzaje, granice, Warszawa 1972.

Winczorek P., Komentarz do Konstytucji Rzeczypospolitej Polskiej, Warszawa 2000.

Winiarz J., Ustalenie wysokości odszkodowania, Warszawa 1962.

Wyrok SA w Poznaniu z dnia 29 września 2005 r., I ACa 236/05, LEX nr 175206.

Wyrok SA w Białymstoku z dnia 24 kwietnia 2013 r., I ACa 787/12, http://orzeczenia.bialystok. sa.gov.pl [dostęp: 1.06.2018].

Wyrok SA w Łodzi z dnia 10 lutego 2016 r., I ACr 341/96.

Wyrok SN z dnia 16 stycznia 1976 r., II CR 692/75, OSNCP 1976, nr 11, poz. 251.

Wyrok SN z dnia 10 czerwca 1977 r., II CR187/77.

Wyrok SN z dnia 23 maja 2002 r., IV CKN 1076/00.

Wyrok SN z dnia 28 lutego 2003 r., V CK 308/02.

Wyrok SN z dnia 26 września 2003 r., IV CK 32/02.

Wyrok SN z dnia 20 maja 2005 r., III CK 595/04.

Wyrok SN z dnia 12 czerwca 2008 r., II CSK 16/08.

Wyrok SN z dnia 8 lipca 2010 r., II CSK 117/10, LEX nr 602677.

Wyrok TK z dnia 7 stycznia 2004 r., K 14/2003, OTK ZU 2004, nr 1A, poz. 1.

Zoll A., Problemy stużby zdrowia w świetle doświadczeń RPO, „Prawo i Medycyna” 2000, nr 8.

\section{SUMMARY}

The article is about compensation responsibility for prenatal injuries also wrongful life and wrongful birth. The study is an attempt to define the concept of harm in the context of the birth of a child and to protect the personal rights of parents in the form of the right to family planning in the event of the birth of a child with a disability. The text also refers to the information obligation of the doctor and medical staff, as well as its scope and method of providing the patient with information about his condition.

Keywords: obligation of information; personal rights; compensation responsibility; prenatal examination 